\title{
Tarefas Matemáticas para o Desenvolvimento da Percepção de Espaço na Educação Infantil: potencialidades e limites
}

\author{
Mathematical Tasks for the Development of Space Perception in Early \\ Childhood Education: potentials and limits
}

\author{
Celma Bento Moreira* \\ Tânia Cristina Rocha Silva Gusmão * \\ Vicenç Font Moll ${ }^{* * *}$
}

\begin{abstract}
Resumo
Este artigo tem como objetivo analisar as potencialidades e limites de tarefas matemáticas, elaboradas com base nos critérios de idoneidade didática, para favorecer o desenvolvimento da percepção de espaço na criança da Educação Infantil. Os critérios de idoneidade didática, ferramentas teóricas do enfoque ontosemiótico, servem para análise e avaliação de processos de ensino e de aprendizagem. Este estudo, de abordagem qualitativa, foi desenvolvido com as crianças do Grupo 3 da Creche da Universidade Federal da Bahia, por meio da implementação de sequências de tarefas. Os resultados revelaram que, de modo global, as sequências de tarefas tiveram um nível de idoneidade didática de médio a alto, contribuindo com um percurso favorável de aproximação das crianças com noções importantes para o desenvolvimento da percepção de espaço, mostrando, em seu conjunto, o potencial das tarefas desenhadas e, portanto, o caráter idôneo da proposta. De modo específico, o critério mediacional, que diz respeito, por exemplo, aos recursos sobretudo materiais, acabou funcionando como um limitante da aprendizagem, uma vez que foi um distrator, desviando a atenção das crianças para outros objetivos de aprendizagem.
\end{abstract}

Palavras-chave: Tarefas Matemáticas. Percepção de Espaço. Educação Infantil. Critérios de Idoneidade Didática.

\begin{abstract}
This article aims to analyze the potentialities and limits of mathematical tasks, elaborated based on the didactic suitability criteria, to favor the development of space perception in children of Early Childhood Education. The criteria of didactic suitability, theoretical tools of the ontosemiotic approach, serve for analysis and evaluation of teaching and learning processes. This qualitative study was developed with the children of Group 3 in the Federal University of Bahia day-care center, through the implementation of task sequences. The results showed that, overall, the task's sequences had a level of didactic suitability from medium-high to high and, although they did not reach a high level of suitability, they played a coherent interrelationship, contributing with a favorable

\footnotetext{
* Mestrado em Educação Científica e Formação de Professores pela Universidade Estadual do Sudeste da Bahia (UESB). Professora da Universidade Federal da Bahia (UFBA), Salvador, Bahia, Brasil. Endereço para correspondência: Creche/UFBA. Rua Padre Feijó, 52, Canela, Salvador/Bahia, CEP: 40.110-170, Brasil. E-mail: celmabm@gmail.com.

** Doutorado em Didática da Matemática pela Universidade de Santiago de Compostela (USC). Professora da Universidade Estadual do Sudoeste da Bahia (UESB), Vitória da Conquista, Bahia, Brasil. Endereço para correspondência: Departamento de Ciências Exatas e Tecnológicas. Estrada do Bem-Querer, km 4, Caixa Postal 95, Vitória da Conquista/BA, CEP: 45083-900, Brasil. E-mail: professorataniagusmao@ gmail.com.

Doctorado en Ciencias de la Educación por la Universitat de Barcelona (UB). Profesor Titular de la Universidad de Barcelona (UB), Barcelona, España. Dirección postal: C/ Fígols, 15, CP 08028, Barcelona, España. E-mail: vicencfont@ono.com.
} 
course of approach for the children, with important notions for the development of space perception, showing, as a whole, the potential of the designed tasks and, therefore, the suitable character of the proposal. Specifically, the mediational criterion, which concerns, for example, material resources, ended up functioning as a learning boundary, since it was a distractor, diverting children's attention to other learning objectives.

Keywords: Mathematical Tasks. Perception of Space. Childhood Education. Didatic Suitability Criteria.

\section{Introdução}

A escola infantil configura-se como um espaço que pode ajudar a criança a organizar as intuições e noções matemáticas que ela encontra no seu dia a dia, proporcionando assim bases sólidas para conhecimentos futuros (DUHALDE; CUBERES, 1998). Nesse sentido, podemos considerar que as noções e conceitos matemáticos que necessitam ser explorados com a criança pequena devem ser feitos com intencionalidade e não de "forma casual ou fortuita" (SMOLE, 2014, p. 43), demandando do(a) professor(a) organização e planejamento das ações que visam a contribuir com a apropriação de noções ou aproximação de conceitos matemáticos pelas crianças.

A efetivação desse planejamento perpassa pela escolha e definição dos métodos de trabalho que serão utilizados, configurando-se como um caminho a ser seguido para se alcançar os objetivos. Entendemos, desse modo, que nos distintos níveis educativos, o que inclui a Educação Infantil, as práticas educacionais que são desenvolvidas, referentes à Matemática, se sustentam por diferentes perspectivas metodológicas, por seus métodos e instrumentos. Nesse contexto, insere-se a escolha que o professor faz pelas tarefas, a análise de qual tipo de tarefas é o mais acertado e mais eficiente para aquele conceito a ser trabalhado, se é o mais adequado para a turma com a qual será desenvolvida etc., de modo que permita ser validado, refutado ou reformulado.

Para uma análise consistente dos métodos e instrumentos, é necessário contar com critérios de avaliação que permitam dissecá-los e estudá-los em diferentes pontos de vista, ou seja, nas suas múltiplas facetas e, para que isso ocorra, necessita-se de uma ferramenta de análise sensível a esta multidimensionalidade (DE CASTRO, 2007). Consideramos os critérios de idoneidade didática propostos por Godino et al. (2006), doravante CID, mais adiante comentados, como ferramenta eficaz para a análise e avaliação dos processos de estudo de um modo geral, visto que dão conta de vários aspectos que precisam ser observados e considerados quando da elaboração e da avaliação de uma proposta de trabalho para a Educação Infantil. 
Nessa perspectiva, e considerando que o nosso estudo busca contribuir com suporte teórico-metodológico que possa auxiliar o(a) professor(a) da Educação Infantil a promover a aproximação das crianças pequenas de importantes conceitos matemáticos no campo geométrico, este artigo tem como objetivo analisar as potencialidades e limites de tarefas matemáticas, elaboradas com base nos critérios de idoneidade didática, para favorecer o desenvolvimento da percepção de espaço na criança da Educação Infantil.

\section{As tarefas matemáticas}

Concebemos as tarefas como contextos e situações diversificadas pensadas e planejadas pelo professor com o intuito de colaborar para uma adequada aprendizagem dos estudantes (POCHULU; FONT; RODRIGUEZ, 2013). As tarefas, nessa perspectiva, assumem um papel fundamental dentro dos processos de ensino e de aprendizagem da Matemática, portanto, para o seu desenho, entendido como processo de elaboração e criação de situações matemáticas a serem aplicadas em sala de aula (POCHULU, et al. 2013, apud GUSMÃO, 2014, p. 6), faz-se necessário considerar os conteúdos que serão trabalhados e os objetivos que se pretendem alcançar, de modo que não sejam eventos isolados, mas que constituam uma organização na qual as tarefas anteriores possam servir de apoio, de experiências que contribuam na solução de tarefas posteriores, formando, assim, uma sequência coerente que favoreça a construção, ampliação, sistematização e consolidação de um ou mais conceitos.

Para que isso se efetive, é necessário "pensar em situações de caráter educativopedagógico intencional, definido, planejado e sistematizado" (AZEVEDO e PASSOS, 2012, p. 55), que busquem mobilizar os conhecimentos que as crianças possuem, muitos deles oriundos das suas vivências anteriores à escola, ampliar e aprimorar esses conhecimentos, além de promover a construção e apropriação de outros novos, historicamente elaborados e socialmente compartilhados.

Assim, baseando-nos no que apontam alguns autores que discutem a Matemática para a Educação Infantil (SMOLE, 1996; DUHALDE; CUBERES, 1998; CHAMORRO, 2005; VECINO, 2005; LORENZATO, 2006; CANALS, 2009), destacamos alguns aspectos que precisam ser considerados quando da elaboração de tarefas: partir do interesse e da curiosidade das crianças; privilegiar as situações lúdicas; contemplar as diversas linguagens e formas de expressão da criança, como a oral, a gestual, a pictórica, a musical, a plástica, a dramática, a corporal etc.; promover processos comunicativos que favoreçam o intercâmbio e 
a exploração de ideias, permitindo que avancem na linguagem e nos modos de representação; favorecer situações que ofereçam experiências desafiadoras, que incentivem as crianças a explorar, observar, comparar, levantar e testar hipóteses, tomar decisões, propor e resolver problemas; contemplar os diversos campos da Matemática, não priorizando um em detrimento de outros, articulando-os sempre que possível e necessário.

\section{A percepção espacial}

As primeiras experiências da criança com o mundo não são de origem quantitativa, mas sim de ordem espacial, que ocorrem quando iniciam o processo de domínio espacial, utilizando-se do próprio corpo (LORENZATO, 2006). Nessa perspectiva, entendemos que as escolas de Educação Infantil precisam promover tarefas que favoreçam o desenvolvimento de noções e conceitos no campo espacial, de modo que possa ampliar, organizar e sistematizar os conhecimentos que a criança constrói na interação com o meio, com os outros (seus pares e adultos) e com os objetos.

Diversos estudos indicam, conforme Smole (1996), que a construção do espaço pela criança se dá de forma progressiva e percorre um caminho que se inicia na percepção de si mesma, passa pela percepção dela no mundo e no espaço ao seu redor, para então chegar ao espaço representado em forma de mapas, croquis, maquetes, representações planas e outras. Entendemos, assim, que essa construção parte do desenvolvimento da percepção espacial, considerada nesse estudo como "a tomada de consciência da situação de seu próprio corpo em um meio ambiente, isto é, do lugar e da orientação que pode ter em relação às pessoas e coisas" (MEUR; STAES, 1991, p.13).

A percepção do espaço na criança avança em uma direção marcada por três etapas essenciais: 1. Espaço vivido - refere-se ao espaço físico, vivenciado através do movimento e do deslocamento e apreendido pela criança por meio de brincadeiras e atividades que permitam percorrer, delimitar ou organizar esse espaço; 2. Espaço percebido - é aquele que não precisa mais ser experimentado fisicamente para que a criança possa lembrar-se dele; 3 . Espaço concebido - surge quando existe a capacidade de estabelecer relações espaciais entre elementos somente através de suas representações, como é o caso de figuras geométricas, mapas, plantas e digramas (SMOLE; DINIZ; CÂNDIDO, 2003; LE BOULCH, 1992).

Nessa perspectiva, entendemos que a evolução da percepção e utilização do espaço pela criança tem estreita relação com a sua interação com o meio, através do movimento e da 
ação, pois a criança faz a "análise do espaço primeiro com o seu corpo, antes de fazê-la com os olhos, para acabar por fazê-la com a mente" (SMOLE; DINIZ; CÂNDIDO, 2003, p. 26).

\section{Os critérios de idoneidade didática}

As sequências de tarefas utilizadas nesse estudo tiveram ainda como base para o seu desenho, e posterior avaliação, os critérios de idoneidade didática ${ }^{1}$. A noção de idoneidade didática e as suas dimensões, introduzidas pelo modelo teórico do Enfoque Ontosemiótico ${ }^{2}$ do Conhecimento e da Instrução Matemática ${ }^{3}$ (EOS), constitui uma síntese orientada para avaliar se as atividades implementadas em sala são idôneas (adequadas), possibilitando melhorar os processos de ensino e de aprendizagem e reestruturá-los, configurando-se, desse modo, como ferramenta para uma didática normativa (FONT; PLANAS; GODINO, 2010).

Os CID, compostos por seis dimensões, são descritos por Godino et al. (2006) como: 1. Idoneidade Epistêmica - grau de representatividade dos significados institucionais implementados ou pretendidos, em relação ao significado de referência; 2. Idoneidade Cognitiva - grau em que as aprendizagens pretendidas/implementadas estão na zona de desenvolvimento potencial dos alunos, assim como a proximidade das aprendizagens adquiridas com as que foram pretendidas ou implementadas; 3. Idoneidade Emocional - grau de implicação (interesse, motivação, atitudes, afetos) do alunado no processo de estudo; 4. Idoneidade Interacional - grau em que os modos de interação entre professor e alunos, aluno e aluno permitem identificar e resolver conflitos de significado e favorecer a autonomia da aprendizagem; 5. Idoneidade Mediacional - grau de disponibilidade e adequação dos recursos materiais e temporais necessários para o desenvolvimento do processo de ensinoaprendizagem; 6. Idoneidade Ecológica - grau em que o processo de estudo se ajusta ao projeto educativo da instituição, às diretrizes curriculares, às condições do entorno social.

Esses critérios juntos permitem contribuir com o planejamento, a implementação e uma posterior valoração dos processos de ensino e de aprendizagem. Porém, por envolver dimensões diversas e que não são diretamente observáveis, Godino et al. (2006) consideram a

\footnotetext{
${ }^{1}$ Critérios de idoneidad didáctica é um termo da língua Castelhana. Considerando que idoneidade/idôneo, em português, possui uma conotação moral (o que seria um erro na interpretação desse construto teórico), na tradução para o Português o termo mais apropriado é critérios de adequação didática, desse modo, idoneidade/ idôneo correspondem a adequação/adequado.

${ }^{2} \mathrm{O}$ Enfoque Ontosemiótico (EOS) é um modelo teórico que objetiva articular e integrar diferentes perspectivas e noções teóricas utilizadas na Educação Matemática a partir de pressupostos antropológicos e semióticos para o estudo dos processos de ensino e aprendizagem matemáticos (FONT; PLANAS; GODINO, 2010).

${ }^{3}$ GODINO et al. (2006) designam "instrução matemática" - o processo de estudo matemático - aos processos de ensino e aprendizagem de conteúdos matemáticos específicos, organizados no âmbito dos sistemas didáticos.
} 
avaliação das atividades pretendidas e efetivamente implementadas em um processo de estudo como algo complexo, demandando, desse modo, de indicadores empíricos (GODINO, 2013) que sirvam como diretrizes para avaliá-las. Como exemplo de indicadores, podemos destacar, para o critério cognitivo, assegurar que os alunos apresentem os conhecimentos prévios necessários para o estudo do tema, e que os conteúdos que se pretende ensinar são alcançáveis, ou seja, apresentam um grau de dificuldade manejável. De modo geral, a aplicação dos critérios e indicadores podem ser melhor visualizados, em nosso estudo, no contexto das análise, mais adiante explicitados.

\section{Percurso metodológico}

Esta pesquisa, de natureza qualitativa, teve como participantes 12 crianças $^{4}$, com idade entre 3 anos e 3 anos e 11 meses, que compunham o Grupo 3 da Unidade de Educação Infantil da Universidade Federal da Bahia/Brasil (Creche/UFBA) e a professora da turma. Essa Unidade de Educação foi escolhida por ser o campo de atuação profissional da pesquisadora, que é professora da Instituição e pela experiência adquirida nesse espaço que fez emergir grande parte das inquietações que contribuíram para a caracterização do objeto em estudo. Já a escolha das crianças se deu em função da faixa etária, considerando que, de um modo geral, já possuem um nível de desenvolvimento que lhes permite a locomoção de muitos modos e com bastante agilidade e desenvoltura, e apresentam uma linguagem com um nível de complexidade mais alto, entre as crianças da creche, com boa capacidade de comunicação oral e vocabulário diversificado, possibilitando uma comunicação mais eficaz com seus pares e adultos. Esses aspectos mostravam-se necessários para o tipo de tarefas que se pretendia desenvolver, que demandava certo domínio corporal e certa apropriação da linguagem oral.

Os dados foram coletados no primeiro semestre de 2016, marcados, em um primeiro momento, por oito encontros com a professora da turma para apresentar e discutir a proposta de trabalho, em específico para estudo das tarefas, seus conteúdos e meios de aplicação, e depois, durante a implementação (pela professora) de três sequências de tarefas (desenhadas pela pesquisadora) que foram distribuídas em doze intervenções (Quadro 1), cujo objetivo era o de aproximar as crianças de noções que contribuíssem para o desenvolvimento da percepção espacial. Nessa perspectiva, as tarefas foram utilizadas com uma dupla função, como suporte

\footnotetext{
${ }^{4}$ A pesquisadora possui autorização para uso de imagens e depoimentos de todos os participantes.
} 
para o desenvolvimento de noções matemáticas e como um método de produção dos dados da pesquisa.

\begin{tabular}{|c|c|c|c|c|}
\hline \multicolumn{5}{|c|}{ Relação das Sequências de tarefas implementadas - período e duração das intervenções } \\
\hline Sequências & Intervenções & Noções abordadas & Data & Duração \\
\hline \multirow{2}{*}{$\begin{array}{l}\text { S1: Ver, ouvir, } \\
\text { tocar... sentir e } \\
\quad \text { expressar }\end{array}$} & 1 - A caixa Mágica & Percepção visual & $17 / 03 / 2016$ & $28 \mathrm{~min}$ \\
\hline & 2 - O saco surpresa & Percepção tátil e auditiva & 07/04/2016 & $37 \mathrm{~min}$ \\
\hline \multirow{7}{*}{$\begin{array}{l}\text { S2: Aqui ou lá, em } \\
\text { todo lugar }\end{array}$} & 1- Estica e enrola & Curvo e reto & 08/04/2016 & $34 \mathrm{~min}$ \\
\hline & 2 - Abre e fecha & $\begin{array}{l}\text { Aberto e fechado; interior e } \\
\text { exterior }\end{array}$ & $13 / 04 / 2016$ & $26 \min$ \\
\hline & $\begin{array}{l}3 \text { - Corre pintinho, } \\
\text { entra no ninho! }\end{array}$ & $\begin{array}{l}\text { Dentro e fora; interior e } \\
\text { exterior }\end{array}$ & $27 / 04 / 2016$ & $\begin{array}{l}25 \min + \\
16 \min \end{array}$ \\
\hline & 4 - Fora seu Lobo! & Dentro e fora & $28 / 04 / 2016$ & $32 \min$ \\
\hline & 5 - Trilha de obstáculos & $\begin{array}{l}\text { Em cima e embaixo; dentro e } \\
\text { fora }\end{array}$ & $29 / 04 / 2016$ & $32 \min$ \\
\hline & $\begin{array}{l}6 \text { - Onde a bola foi } \\
\text { parar? }\end{array}$ & $\begin{array}{l}\text { Em/por cima e embaixo; dentro } \\
\text { e fora }\end{array}$ & 05/05/2016 & $18 \mathrm{~min}$ \\
\hline & 7 - A galinha choca & Em cima e embaixo; do lado & 06/05/2016 & $21 \mathrm{~min}$ \\
\hline \multirow{3}{*}{$\begin{array}{c}\text { S3: "Prá lá e prá } \\
\text { cá, vou a qualquer } \\
\text { lugar!" }\end{array}$} & 1 - Caminho orientado & Entre duas coisas & $11 / 05 / 2016$ & $24 \mathrm{~min}$ \\
\hline & 2 - Corrida de velotrol & $\begin{array}{l}\text { Para frente, para trás/para o } \\
\text { lado; por dentro }\end{array}$ & $12 / 05 / 2016$ & $20 \min$ \\
\hline & $\begin{array}{l}3 \text { - Circuito de corrida } \\
\text { de carrinhos }\end{array}$ & $\begin{array}{l}\text { Para cima e para baixo, para } \\
\text { frente e para trás/para o lado; } \\
\text { por dento; por baixo }\end{array}$ & $19 / 05 / 2016$ & $26 \min$ \\
\hline
\end{tabular}

Quadro 1 - Sequências/ intervenções implementadas Fonte: Organização nossa (2016).

A pesquisa qualitativa possibilita uma diversidade grande de procedimentos e instrumentos, por ser caracteristicamente multimetodológicas, tendo entre as técnicas mais utilizadas a observação (participante ou não), a entrevista em profundidade e a análise de documentos (ALVES-MAZZOTTI, 2000). Nessa perspectiva, para a captação dos dados utilizamos a observação participante que mostrou-se um método bastante coerente, visto que as intervenções foram desenvolvidas pela professora, em parceria com a pesquisadora, no contexto da sala de aula.

No tocante aos instrumentos, um conjunto deles ajudou a cercar o fenômeno estudado. O diário de campo foi utilizado no intuito de registrar as informações e percepções que foram surgindo durante as observações; já as fotografias foram utilizadas para o registro e ilustração do processo, possibilitando a constatação das ações ocorridas; a filmagem, em áudio e vídeo, outro excelente aliado nessa pesquisa, foi utilizada como meio de captura e registro dos processos de comunicação das crianças que se dão também, em grande parte, pelos gestos, olhares e posturas que assumem durante uma atividade e que revelam muito do que estão 
sentindo; os materiais produzidos pelas crianças, como os desenhos e as colagens, constituíram ricos documentos de registros que possibilitaram acessar diferentes modos de representação da criança e também compreender como entendiam as tarefas; e por último, porém não menos importante, utilizamos o questionário aplicado à professora, participante da pesquisa, que nos permitiu acessar as informações provenientes da sua reflexão sobre as sequências de tarefas, a implementação das mesmas e a participação das crianças. Acreditamos que dar voz à professora, trazendo o seu ponto de vista e sua reflexão sobre o processo somaria com a nossa análise, contribuindo para uma maior confiabilidade e validação dos resultados, visto que ela esteve diretamente envolvida e implicada em todo o processo de estudo e implementação das sequências de tarefas.

As informações contidas no conjunto desses instrumentos foram analisadas considerando as tarefas de forma integrada, utilizando como base os Critérios de Idoneidade Didática, os quais também serviram de categorias para análise. Cabe ressaltar que, mesmo utilizando categorias pré-definidas (os critérios), as tarefas foram analisadas de forma integral.

\section{Apresentação e análise dos dados}

Por se tratar de uma pesquisa no nível da Educação Infantil, cujos processos de aprendizagem e desenvolvimento diferem, em certa medida, dos estudantes de outros níveis de escolaridade, e dado que o marco teórico adotado está sendo, pela primeira vez, aplicado a este nível de ensino, tivemos o cuidado de fazer as adaptações e enriquecimentos necessários aos indicadores empíricos propostos para a operacionalização dos critérios de idoneidade didática do EOS, para que estes correspondessem ao contexto da Educação Infantil.

Para melhor visualização e entendimento, organizamos os indicadores empíricos em três quadros distintos, cada um representando uma categoria de análise e agrupando duas das dimensões que compõe os critérios de idoneidade didática: epistêmico/ecológico, cognitivo/afetivo e mediacional/interacional. Essa organização em pares justifica-se pela inter-relação existente entre essas dimensões, pois, segundo Godino (2013), as noções de idoneidade epistêmica e ecológica, associadas, constituem a base para uma teoria do currículo; a cognitiva e afetiva constituem a base para uma teoria da aprendizagem; enquanto a interacional e mediacional, por sua vez, a base para uma teoria do ensino.

Assim, em cada quadro apresentamos os aspectos de cada categoria contemplados no desenho das tarefas (processo de estudo pretendido) para que estas tivessem um alto grau de idoneidade didática. Após cada quadro, fazemos uma breve descrição das três sequências 
implementadas, considerando os aspectos contemplados no quadro/categoria. Por último, apresentamos uma discussão geral em torno da categoria analisada e sobre que aspectos desta foram evidenciados durante a implementação das sequências, trazendo, ainda, nessa discussão, fragmentos de fala da professora das crianças, que expressam sua reflexão sobre o trabalho realizado, ao passo que contribuem para validar o nosso estudo.

\subsection{Categoria de análise - Idoneidade epistêmica/ecológica}

Aspectos contemplados nas tarefas /indicadores empíricos para a Idoneidade epistêmica/ecológica

- Introduz e amplia a linguagem matemática verbal de forma clara e compassada;

- Promove a construção e socialização de hipóteses de forma espontânea, propicia a argumentação, contestação e verificação das hipóteses;

- Contemplam os documentos oficiais e o currículo local;

- Promove conhecimento matemático, integrando os diversos campos, articulando esses conhecimentos com os relativos ao mundo físico, social, cultural e natural;

- Favorece diversas linguagens e formas de expressão da criança pequena (gestual, oral, corporal, musical, pictórica etc.).

Quadro 2 - Categoria de análise - Idoneidade epistêmica/ecológica

Fonte: Organização nossa, adaptado de Godino (2013).

Sequência 1: Ver, ouvir, tocar... sentir e expressar!

As tarefas propostas nessa sequência permitiram explorar e aprimorar a habilidade de atenção e observação das crianças, além da evocação e da verbalização, estimulando a discriminação e memória visual e tátil (Figura 1). Além disso, promoveram aproximação e exploração de algumas noções relativas ao campo Espaço e Forma (dentro/fora, em cima/embaixo, aberto/fechado) e o das Medidas (longe/perto, grande/pequeno), que contribuirão posteriormente com a apropriação de alguns conceitos (distância, posição, tamanho e forma), por meio de comparação entre objetos (Figura 2) durante as brincadeiras, utilizando, para isso, linguagem matemática específica e com a clareza esperada para o nível das crianças. As tarefas também promoveram a argumentação, a formulação e verificação de hipóteses quanto aos objetos que podiam ou não estar dentro de um determinado espaço e quanto às mudanças ocorridas na posição dos objetos, estimulando o uso da linguagem oral e da gestual (Figura 3). 


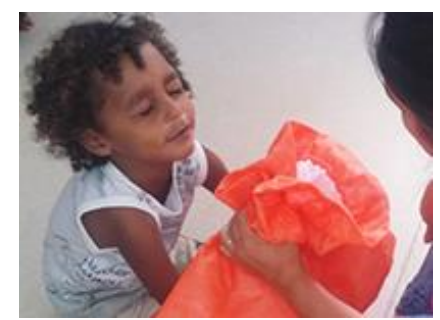

Figura 1 - Discriminação tátil

Fonte: Acervo Pessoal (2016)

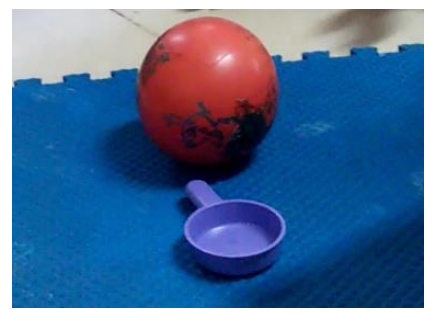

Figura 2 - Comparação entre objetos

Fonte: Acervo Pessoal (2016)

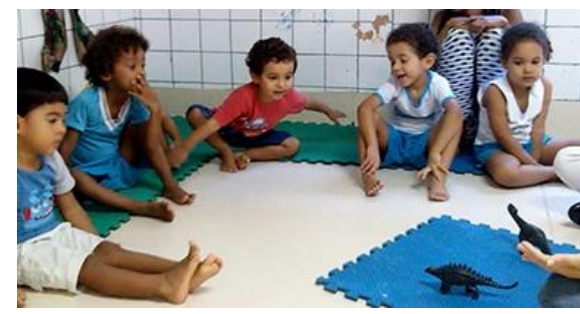

Figura 3 - Linguagem gestual Fonte: Acervo Pessoal (2016)

Sequência 2: Aqui ou lá, em todo lugar!

Nessa sequência as tarefas permitiram introduzir noções relativas à forma (curvo/ reto e aberto/fechado) e à posição e localização no espaço (dentro/fora, interior/exterior/limite, em cima/embaixo/do lado), com linguagem clara e compatível com as crianças, porém sem deixar de utilizar os signos adequados com a linguagem matemática. Além da linguagem verbal, utilizaram-se outros modos de representar e contextualizar as noções, com desenho, objetos manipuláveis, cenários de histórias, brinquedos e brincadeiras (Figura 4 e 5), e, para a argumentação, formulação e verificação de hipóteses, as crianças também foram estimuladas a utilizar outras formas de expressão, como gestos, desenhos e modelagem (Figura 6).

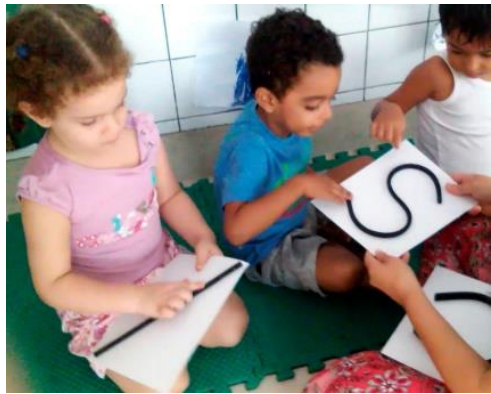

Figura 4 - Objeto manipulável Fonte: Acervo Pessoal (2016).

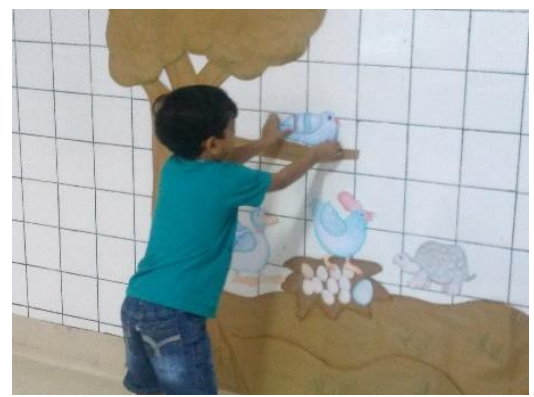

Figura 5 - Desenhos/cenários Fonte: Acervo Pessoal (2016).

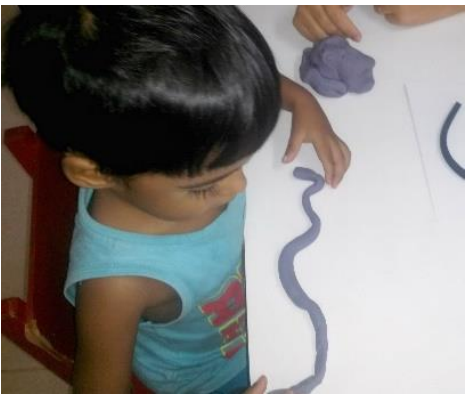

Figura 6 - Modelagem Fonte: Acervo Pessoal (2016).

As tarefas dessa sequência buscaram ainda contemplar outros campos da Matemática, como o numérico e o das medidas, a exemplo da utilização da contagem oral (dos ovos) (Figura 5), comparação de tamanho e de quantidade (entre ovos da galinha e da pata, entre os pintinhos e o patinho), assim como integrar conhecimentos do mundo natural e social.

\section{Sequência 3: Pra lá e pra cá, vou a qualquer lugar!}

As tarefas propostas nessa sequência favoreceram a ampliação de algumas noções de localização (entre, por cima/por baixo) e a inserção de noções de orientação - direção e sentido (para cima/para baixo, para frente/para trás/para o lado), utilizando a linguagem matemática verbal, objetos manipuláveis e brincadeiras. 
Essas diferentes formas de representação e contextualização das noções propostas trouxeram o corpo como primeira referência e elemento central, como no caminho orientado e na corrida de velotrol (Figura 7 e 8), e foi, aos poucos, ampliando e extrapolando para relações espaciais mais amplas entre objetos e referenciais fixos, a exemplo dos carrinhos e da pista que formava o circuito de corrida, com suas curvas, elevados, viadutos, túneis e estacionamento (Figura 9).

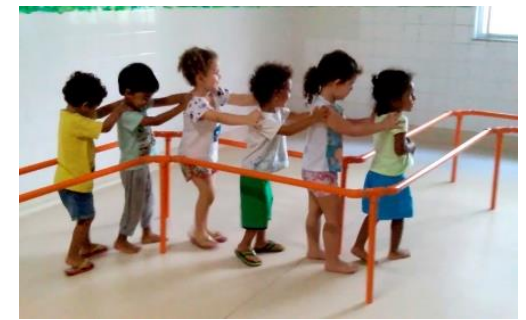

Figura 7 - Caminho orientado Fonte: Acervo Pessoal (2016).

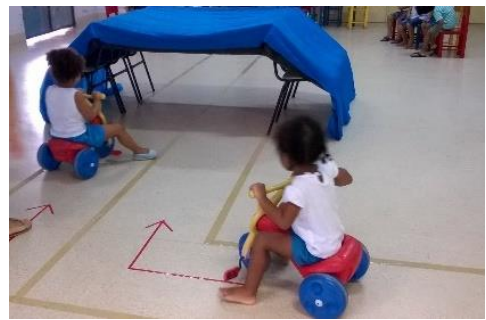

Figura 8 - Corrida de motoca Fonte: Acervo Pessoal (2016).

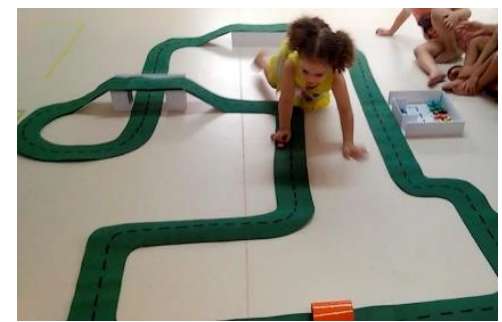

Figura 9 - Circuito de corrida Fonte: Acervo Pessoal (2016).

Avaliação global da idoneidade epistêmicalecológica das sequências

Garantir experiências que recriem em contextos significativos relações espaciais é um dos aspectos contemplados nas Diretrizes Curriculares Nacionais para a Educação Infantil (BRASIL, 2010), assim como na proposta curricular da Creche/UFBA, que preconiza atividades que explorem uma variedade de ideias matemáticas relativas a números, medidas, espaço e forma, por meio de situações cotidianas significativas que busquem conservar o prazer e a curiosidade das crianças (CRECHE UFBA, 2012). Desse modo, as sequências de tarefas, ao proporcionarem experiências que aproximaram as crianças de noções relativas ao campo espacial, articulando-as com outros campos matemáticos e outras áreas do conhecimento norteadoras do desenvolvimento infantil, como a natural, social e cultural, sempre que possível, contemplaram o currículo oficial e local, o que pode ser corroborado com a fala da professora, quando questionada sobre as tarefas estarem em consonância com a proposta Curricular da Creche/UFBA e com as Diretrizes Curriculares Nacionais para a Educação Infantil:

Sim. Tanto as Diretrizes Curriculares Nacionais para a Educação Infantil quanto a Proposta Curricular da Creche/UFBA compreendem que a brincadeira e as interações devem permear todo o trabalho da educação infantil, e isso ficou evidente nas tarefas. Além disso, a experiência de exploração relacionada à matemática, à ampliação de conceitos e interrelação entre os campos matemáticos, presentes nas tarefas, estão preconizados nesses documentos (Questionário, 2016).

Além dos aspectos relativos à Matemática, a professora enfatiza ainda as brincadeiras que permearam todas as tarefas. Nesse sentido, podemos destacar a sua importância para o desenvolvimento das crianças e para o seu processo de aprendizagem de modo global, pois, 
ao brincar, a criança se depara com desafios e problemas para os quais deve buscar soluções constantemente. $\mathrm{O}$ ato de brincar, nesse sentido, é também uma forma de resolver problemas (SMOLE, 1996). A professora destaca ainda os aspectos relativos à integração entre os campos matemáticos e outras áreas do conhecimento que fazem parte do desenvolvimento infantil.

Em relação aos campos matemáticos, houve a relação entre o numérico e o das medidas (como na história da galinha choca - que entram esses dois campos). Com outras áreas de conhecimento, pude perceber a relação com a linguagem escrita e oral (era constante), com as artes plásticas (pintura, colagem, modelagem), musicais (vários momentos) e cênicas (como na brincadeira do pintinho e do gavião e dos três porquinhos), com natureza (aspectos relacionados aos animais, alimentação, diferenças, forma de nascimento (ovo) na história da Galinha Choca) e com sociedade (os esportes - vôlei, futebol, basquete), movimentos, brincadeiras e interações (Questionário, 2016).

Da análise foi possível observar que vários indicadores empíricos previstos quando da elaboração das tarefas foram contemplados durante a sua implementação, podendo considerar que houve, globalmente, uma alta idoneidade epistêmica e ecológica.

\subsection{Categoria de análise - Idoneidade cognitiva/afetiva}

Aspectos contemplados nas tarefas / indicadores empíricos para a Idoneidade cognitiva/afetiva

- Partem dos conhecimentos das crianças e proporcionam ampliação, organização e sistematização de novos conhecimentos;

- Apresentam desafios possíveis de serem alcançados, respeitam a capacidade de resposta das crianças, demandando atenção, observação, evocação e verbalização;

- Propiciam a valorização das respostas das crianças, da sua participação e interesse;

- Introduzem e exploram as noções e conceitos por meio de elementos que despertam o interesse das crianças e as motivam a participar ativamente.

Quadro 3 - Categoria de análise - Idoneidade cognitivalafetiva Fonte: Organização nossa, adaptado de Godino (2013).

Sequência 1: Ver, ouvir, tocar... sentir e expressar!

As tarefas proporcionaram a identificação de objetos escondidos, primeiro em uma caixa, depois em um saco, apenas pelo toque ou por meio de dicas (atributos quanto à forma, tamanho, utilidade etc.), que variavam em quantidade, de acordo com as dificuldades apresentadas pelas crianças, respeitando a capacidade de respostas delas; possibilitaram também que as crianças utilizassem suas percepções anteriores e a relação direta entre atributos e tipos de objetos, levando-as à evocação e verbalização (Figura 10).

Ao demandarem o uso de poema, brinquedos e objetos que tinham relação direta com as crianças, as sequências desenhadas estimularam a participação e interesse delas. Além 
disso, durante as tarefas, as diversas formas de expressão das crianças foram apreciadas e incentivadas, e, independentemente de serem mais falantes ou introvertidas e de utilizarem gestos, todas as suas manifestações de aprendizagem foram observadas e valorizadas.

Nessa sequência, as tarefas apresentaram baixo grau de dificuldade na fase inicial, permitindo que todas as crianças tivessem acertos, estimulando-as a uma participação ativa, apresentando cada vez mais confiança em suas habilidades. Assim, por exemplo, quando tiveram que descrever os objetos que sumiram ou foram deslocados e a posição em que se encontravam, os níveis de dificuldade foram sendo aumentados de forma gradativa, dispondo dois objetos e sumindo um, depois dispondo três e sumindo dois etc. (Figura 11).

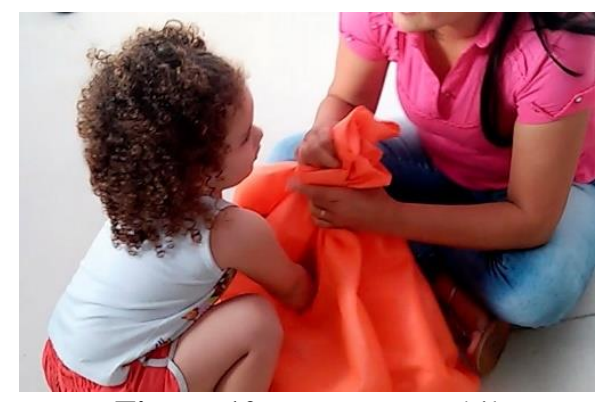

Figura 10 - Percepção tátil Fonte: Acervo Pessoal (2016).

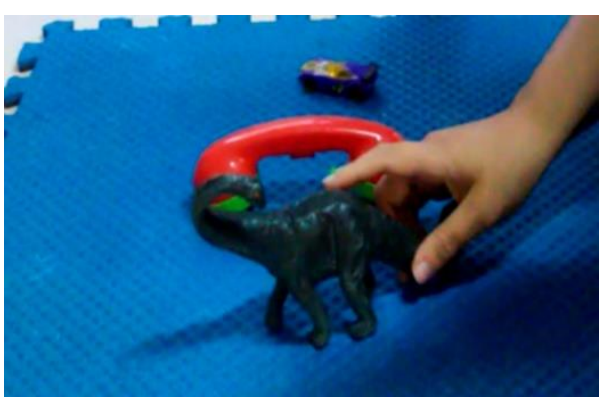

Figura 11 - Três objetos Fonte: Acervo Pessoal (2016).

\section{Sequência 2: Aqui ou lá, em todo lugar!}

As tarefas partiram dos conhecimentos das crianças, e buscaram ampliá-los e sistematizá-los por meio de brincadeiras, da exploração de objetos manipuláveis e de desenhos (Figura 12), promovendo desafios condizentes com as suas capacidades de respostas. Ademais, promoveram a exploração de noções, por meio de músicas e brincadeiras, que demandaram movimento e vivência corporal, contextualizadas com objetos e brinquedos que possuíam relação direta com as crianças, o que despertou o seu interesse, motivando-as a uma participação ativa. Isso pôde ser notado, também, quando algumas noções foram exploradas, ampliadas e sistematizadas, por meio de histórias contadas de forma lúdica e com a utilização de cenários e fantoches (Figura 13).

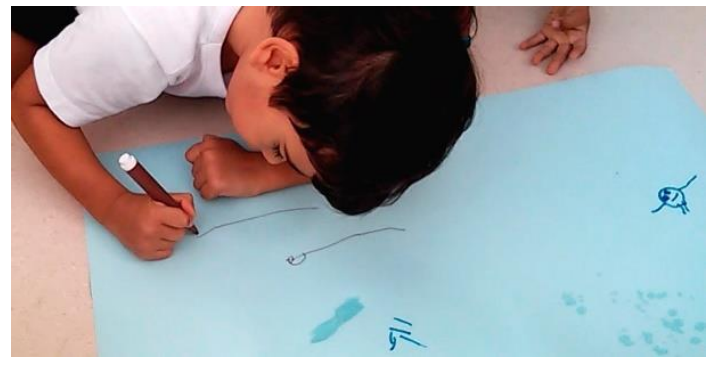

Figura 12 - Desenho conhecimentos prévios Fonte: Acervo Pessoal (2016).

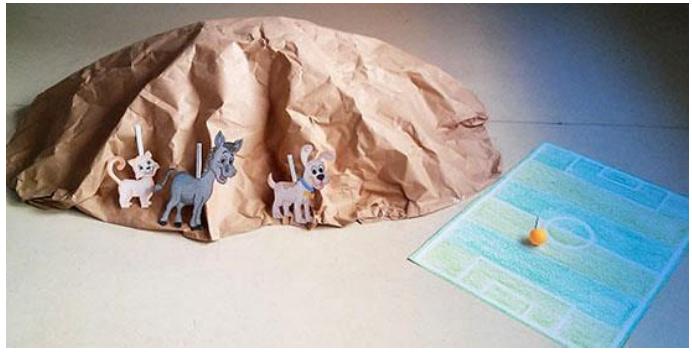

Figura 13 - Cenário de história Fonte: Acervo Pessoal (2016). 
As tarefas, de forma lúdica e atraente, possibilitaram às crianças a identificação da posição do próprio corpo (dentro/fora, interior/exterior de uma região) em relação a um referencial fixo - ninho (bambolê) e casinha de parque - como na brincadeira ${ }^{5}$ do pintinho e do gavião, na qual as crianças perceberam e compreenderam a distinção entre as regiões interior e exterior, tendo o contorno do bambolê como limite entre essas duas regiões, bem como durante a brincadeira "Fora, Seu Lobo", na qual elas precisaram se posicionar dentro da casinha para se proteger do lobo. Desse modo, propiciou a ampliação das experiências e conhecimentos das crianças, como esperado.

\section{Sequência 3: Pra lá e pra cá, vou a qualquer lugar!}

Nessa sequência, as tarefas partiram das noções exploradas nas sequências anteriores, de modo que serviram de base para a ampliação e a sistematização de novos conhecimentos das crianças. Foram utilizadas brincadeiras, brinquedos e materiais manipuláveis e atraentes, que despertaram o interesse das crianças, estimularam a sua participação, além de promoverem a estruturação de noções espaciais relativas à localização/posição e a aproximação delas com importantes noções relativas à orientação espacial (direção e sentido), envolvendo a exploração sensorial (Figura 14), estratégias de deslocamento corporal no ambiente, por meio de percurso orientado (Figura 15) e depois ampliando para o deslocamento e a relação espacial entre objetos (Figura 16).

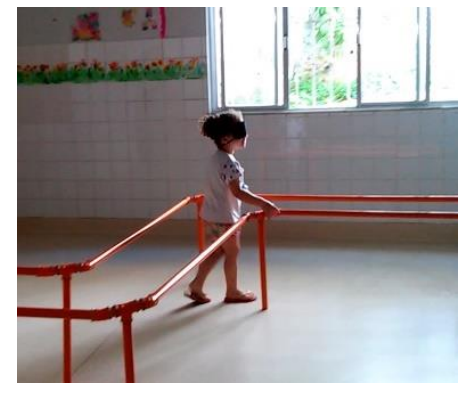

Figura 14 - Exploração sensorial Fonte: Acervo Pessoal (2016).

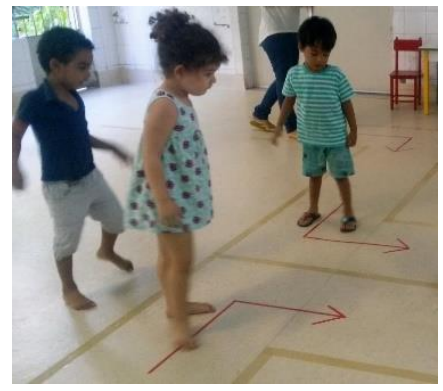

Figura 15 - Percurso orientado Fonte: Acervo Pessoal (2016).

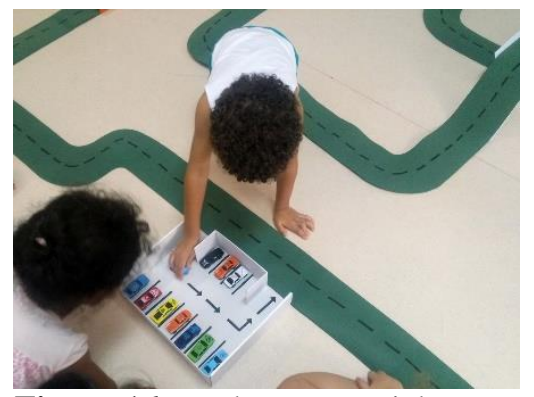

Figura 16 - Relação espacial entre objetos

Fonte: Acervo Pessoal (2016).

Avaliação global da idoneidade cognitivolafetiva das sequências

De modo geral, as crianças demonstraram ter os conhecimentos necessários para a introdução das noções exploradas e acompanhar a ampliação e sistematização de tais noções. Avanços puderam ser percebidos em situações que precisaram estabelecer relações de posição (dentro/fora, interior/exterior, em cima/embaixo). Entretanto, em uma das atividades, apesar

\footnotetext{
${ }^{5}$ As brincadeiras utilizadas nas tarefas foram adaptadas de brincadeiras tradicionais infantis de domínio público.
} 
de terem feito os percursos das brincadeiras que envolviam relações de orientação (direção e sentido no eixo horizontal - para frente, para trás e para os lados) com pleno envolvimento e entusiasmo, notamos que as crianças se atrapalhavam um pouco para seguir os comandos dados pela professora.

Essa dificuldade pode ser compreendida ao considerar que noções de direção e sentido no eixo horizontal (frente/atrás e direita/esquerda) são mais complexas, pois, ao rotacionar o corpo, o que está em um lado passa a estar do outro e o que está à frente passa a estar atrás, o que difere do eixo vertical (acima e abaixo), no qual é possível distinguir e diferenciar com mais facilidade o que está no teto e o que está no chão (DUHALDE; CUBERES, 1998). Desse modo, alguns desafios promovidos na intervenção 3, em parte, não foram condizentes com a capacidade de resposta das crianças, mas, apesar disso, contribuíram para o desenvolvimento da sua competência espacial.

No que tange ao interesse, nível de participação e engajamento das crianças, consideramos que as tarefas foram muito eficientes. A fala da professora legitima nosso entendimento, ao relatar que a participação das crianças foi muito boa:

As crianças demonstraram prazer em participar das tarefas, nos momentos de concentração, seus olhos fixos e brilhando, sorrisos entre os lábios mostraram esse envolvimento. E em outros momentos, quando a proposta envolvia movimento, as crianças vibravam, se divertiam, pulavam e corriam com muito prazer (Questionário, 2016).

Diante do que foi descrito e a partir das observações feitas consideramos o resultado satisfatório, pois o trabalho conseguiu promover a ampliação, organização e sistematização de novos conhecimentos das crianças, de modo interessante e significativo. O que pode ser validado pela fala da professora, que destaca alguns avanços cognitivos observados nas crianças, quanto à percepção de espaço:

O uso, na fala, em momentos posteriores, de noções apresentadas, como: dentro e fora, para cima e para baixo, em cima e embaixo, mostraram esse avanço. Um momento interessante para exemplificar, que aconteceu posterior a uma tarefa, foi que as crianças continuaram brincando com os bambolês de pintinhos e gavião e utilizando as expressões dentro e fora, como acontecia na tarefa. Além disso, as crianças demonstram avanços, através de brincadeiras e de representação em papel, como por exemplo: - Em um momento posterior a uma tarefa da pesquisa (de circuito de corrida com carrinhos de brinquedos), porém no mesmo dia, duas crianças que permaneciam brincando com os carrinhos, solicitaram papel e caneta e desenharam a pista representando o circuito que tinha sido realizado na tarefa e brincaram com os carrinhos, colocando-os sobre a pista desenhada (Questionário, 2016).

Assim, podemos constatar que alguns indicadores empíricos foram contemplados na totalidade durante a implementação das sequências, enquanto outros, de forma parcial, o que nos permite avaliar que globalmente, nas três sequências, as idoneidades cognitiva e afetiva tiveram grau moderadamente alto. 


\subsection{Categoria de análise - Idoneidade mediacional/interacional}

Aspectos contemplados nas tarefas / indicadores empíricos para a Idoneidade mediacional/interacional

- Preveem tempo de execução suficiente para que todas as crianças participem e se mantenham concentradas e com interesse;

- Propõem a organização das crianças em um único grupo, na maioria das vezes, assim como a organização individual em momentos específicos;

- Preveem espaços adequados para a sua realização;

- Permitem a participação individual e coletiva das crianças, respeitando a individualidade e o ritmo de cada uma, possibilitando ainda um aprendizado colaborativo;

- Utilizam brincadeiras, música e elementos lúdicos como brinquedos e objetos que permitem uma boa introdução das noções e conceitos, além de favorecem a imaginação e a comunicação, facilitando a inclusão e o envolvimento das crianças;

- Propicia materiais de fácil manipulação e adequados para crianças, em quantidade suficiente para o uso individual e coletivo;

- Propõe a utilização de uma linguagem clara e compassada, condizente com as crianças;

- Propicia jogos de pergunta e respostas, estimulando processos comunicativos, como os diálogos entre a professora e as crianças e entre as crianças favorecendo a identificação de conflitos cognitivos e a resolução deles.

Quadro 4 - Categoria de análise - Idoneidade mediacional/interacional Fonte: Organização nossa, adaptado de Godino (2013).

Sequência 1: Ver, ouvir, tocar... sentir e expressar!

Os materiais utilizados durante as tarefas, como os que compuseram a caracterização do mágico (capa, cartola, varinha e caixa mágica), o modo entusiasmado e os aspectos lúdicos que envolveram a performance da professora ao recitar o poema aguçaram a curiosidade e imaginação das crianças. O saco surpresa, os brinquedos e objetos mostraram-se atrativos, de fácil manipulação e adequados para o nível cognitivo e etário das crianças, favorecendo a inclusão e o envolvimento das mesmas.

O local escolhido para a realização das tarefas foi adequado para a proposta, já a organização das crianças, em um único grupo, foi adequado para algumas tarefas nas quais permitiu a participação individual e coletiva (Figura 17), mas, para outras tarefas, essa organização não se mostrou satisfatória, pois durante a participação individual, as outras crianças tiveram que aguardar como espectadoras, o que provocou dispersão (Figura 18).
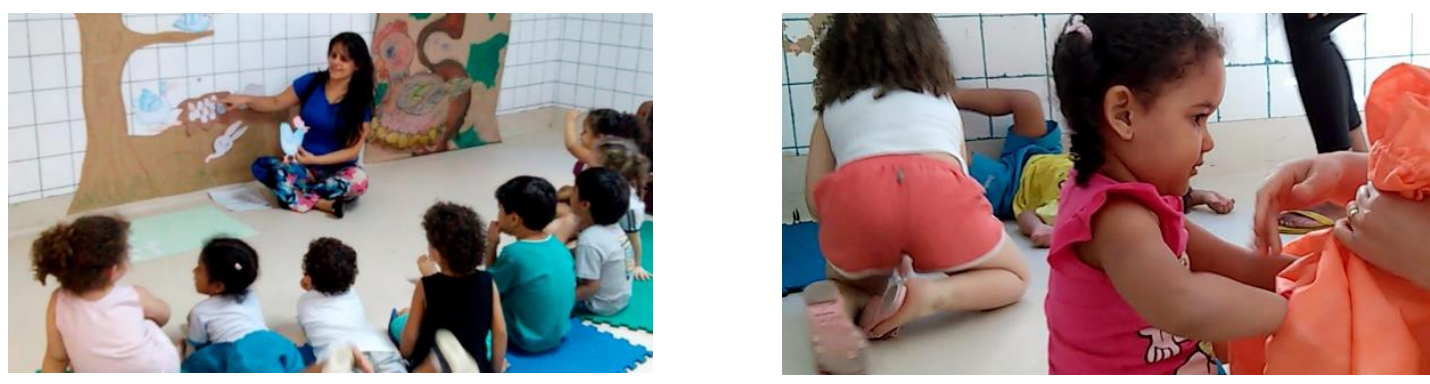
Figura 17 - Organização em um único grupo/concentração Fonte: Acervo Pessoal (2016).
Figura 18 - Participação individual/dispersão Fonte: Acervo Pessoal (2016).

Já os processos de interação contribuíram com a argumentação, a formulação e verificação de hipóteses, por meio dos jogos de perguntas e respostas conduzidos pela professora. Porém, em um dos episódios que envolvia descobrir o que tinha dentro da caixa do mágico, diante da resposta de uma criança que afirmou que havia um carro (de fato havia um carro de brinquedo), a professora se antecipou e formulou a hipótese "um carro de verdade!" (referindo-se ao carro meio de transporte) quando poderia estimular as crianças a formularem outras hipóteses por meio de indagações. Utilizou ainda um vocabulário que provocou um conflito de sentido (o carro de brinquedo também é de verdade, não é fruto da imaginação), dificultando o avanço das crianças na percepção das diferenças de tamanho dos carros, como aspecto principal para que não pudesse estar dentro da caixa.

Em muitos outros momentos a interação da professora foi assertiva, com um olhar sensível e cuidadoso, e, atenta aos diferentes modos de expressão das crianças, estimulou as mais introvertidas, demonstrando respeito à individualidade. Além disso, utilizou termos adequados durante a exploração de noções ou propriedades, introduzindo novos signos, ampliando o repertório das crianças e promovendo o acesso a uma linguagem específica. Ademais, os processos comunicativos durante a tarefa permitiram à professora reconhecer um conflito de significado, ao interpretar a possível origem na divergência das respostas das crianças quanto ao tamanho do objeto (grande/pequeno) - a falta de um referencial -, ao tempo que permitiu resolvê-lo promovendo a comparação direta entre os objetos.

\section{Sequência 2: Aqui ou lá, em todo lugar!}

Os materiais, de fácil manipulação, utilizados nessa sequência estavam em quantidade suficiente para o uso individual e coletivo das crianças. A organização das crianças em um único grupo, na maioria das tarefas, permitiu a participação coletiva contribuindo com um aprendizado colaborativo, assim como a organização individual em outras tarefas possibilitou uma atenção mais apurada a cada criança e o respeito ao seu ritmo.

Os espaços escolhidos para a realização das tarefas, sala, pátio (grande e coberto), foram adequados, assim como o tempo de realização das tarefas, suficientes para a participação de todas as crianças com concentração.

Além disso, os cenários das histórias A galinha choca, Os três porquinhos e Onde a bola foi parar? e os objetos - cartelas, bambolês, caixas de papelão, casinhas em miniatura, 
boneco de personagens, cadeiras, massinha de modelar etc. (Figuras 19 e 20) - estimularam o interesse e participação das crianças, bem como o modo como eles foram utilizados, e os processos comunicativos conduzidos pela professora durante a exploração contribuíram para uma boa introdução das noções relativas à localização/posição (dentro/fora, interior/exterior, em cima/embaixo, entre) e relativas à orientação espacial - direção e sentido (para frente/para trás, para cima/para baixo, para o lado).

As tarefas privilegiaram momentos nos quais as crianças deveriam observar as orientações definidas previamente ou imitar a professora e os colegas, e outras em que puderam agir como protagonistas - escolhendo e definindo os modos de participar - o que permitiu que elas fossem ouvidas nos seus desejos e nas formas de pensar, favorecendo uma participação mais independente e engajada (Figura 21).

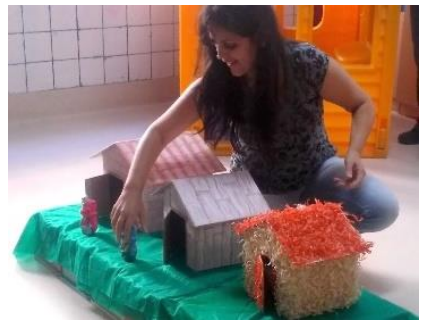

Figura 19 - Cenário de história Fonte: Acervo Pessoal (2016).

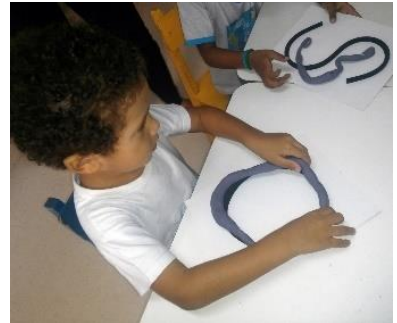

Figura 20 - Cartelas e massinha

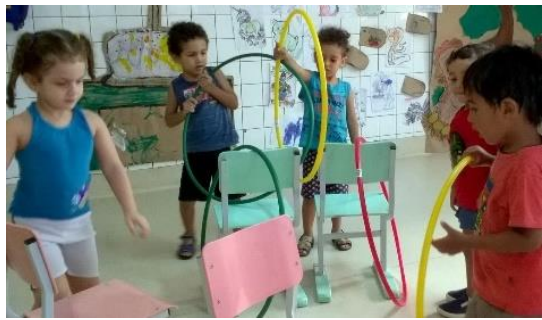

Figura 21- Protagonismo/engajamento Fonte: Acervo Pessoal (2016).

Fonte: Acervo Pessoal (2016)

Os processos comunicativos, como jogos de pergunta e respostas propostos pela professora durante e após as vivências corporais nas brincadeiras (fig. 22 e 23), estimularam a evocação e a verbalização da situação vivida e contribuíram, ademais, para uma representação gráfica pelas crianças (Figura 24), o que revelou certa compreensão das noções em contextos diferentes.

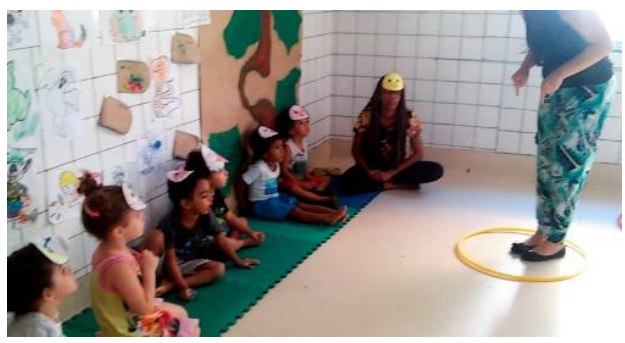

Figura 22 - Brincadeira "O pintinho e o gavião"

Fonte: Acervo Pessoal (2016).

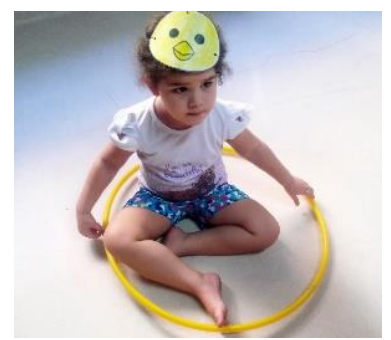

Figura 23 - Pintinho dentro do ninho

Fonte: Acervo Pessoal (2016).

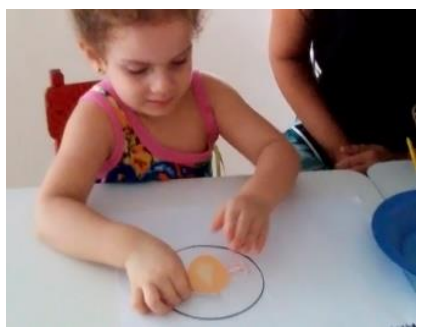

Figura 24 - Representação gráfica

Fonte: Acervo Pessoal (2016).

Sequência 3: Pra lá e pra cá, vou a qualquer lugar!

Nessa sequência, o tempo reservado para as tarefas, assim como os espaços escolhidos, a organização da turma em um único grupo, mostraram-se adequados e 
condizentes com as noções que se pretendia trabalhar.

Os materiais utilizados nas brincadeiras, como as barreiras em $3 \mathrm{~d}$, a pista para a corrida de velotrol, o circuito de corrida e os carrinhos (Figura 25), além de estarem em quantidade suficiente para a participação coletiva e individual das crianças e serem de fácil manipulação, o modo como foram organizados e explorados tiveram uma forte contribuição para a ampliação e sistematização de algumas noções já trabalhadas, assim como para introdução de outras noções em contextos diferentes, como a representação gráfica (Figuras 26 e 27).

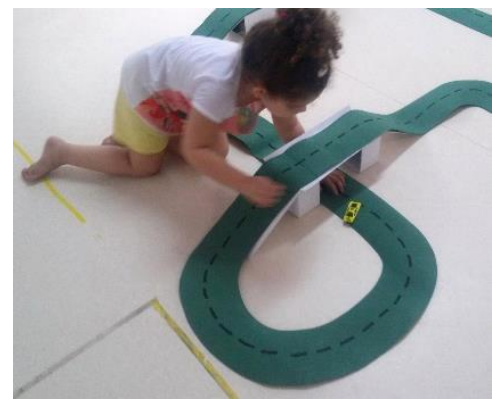

Figura 25 - Circuito de corrida Fonte: Acervo Pessoal (2016).

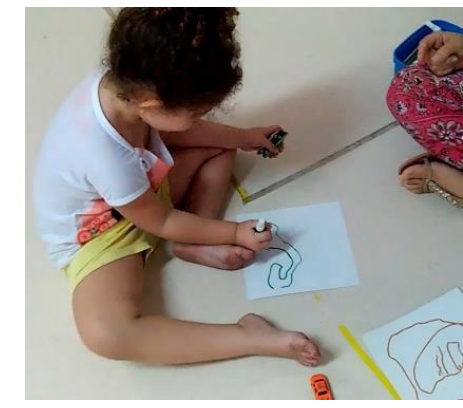

Figura 26 - Representação gráfica do circuito

Fonte: Acervo Pessoal (2016o).

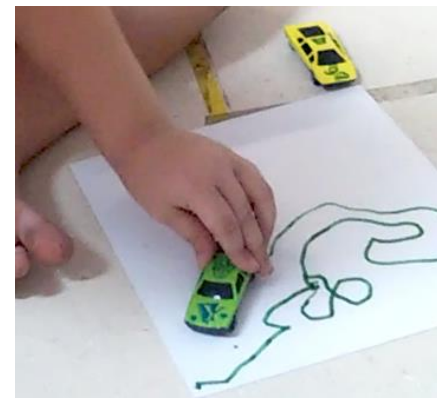

Figura 27 - Diferentes contextos

Fonte: Acervo Pessoal (2016)

Interações decorrentes das brincadeiras, como a observação dos modos de agir dos colegas e o diálogo entre as crianças, contribuíram para que decidissem quanto ao uso de diferentes estratégias durante os desafios propostos. Como exemplo, podemos citar a exploração do caminho orientado, onde as crianças tiveram que fazer o percurso mantendo-se entre barreiras em 3d, tanto individualmente, com os olhos vendados, como juntos, formando um trenzinho, e, para cada situação, mobilizaram modos diferentes de agir, andaram mais devagar, utilizaram da percepção tátil com o apoio das mãos para se orientar etc.

Além disso, os diálogos conduzidos pela professora durante a realização de algumas brincadeiras, como a do circuito de corrida de carrinhos, ora com questionamentos, ora com afirmações de sistematização, contribuíram para que as crianças pensassem com e sobre as situações que estavam vivenciando na exploração de relações espaciais entre objetos, promovendo avanços no aprendizado das crianças.

\section{Avaliação global da idoneidade mediacional/interacional das sequências}

Em todas as sequências os espaços escolhidos foram adequados e os recursos materiais se apresentaram condizentes com o desenvolvimento das tarefas, em quantidade suficiente e com a qualidade necessária para explorar de forma eficiente e diversificada as noções 
pretendidas e despertar o interesse das crianças. Nesse sentido, a professora destaca como aspecto positivo para as tarefas a qualidade dos materiais:

Os materiais utilizados, por facilitar o desenrolar das tarefas, serem adequados às idades das crianças, pela beleza e criatividade (Questionário, 2016).

Cita ainda os materiais que, em sua opinião, facilitaram a aproximação e a compreensão de noções matemáticas pelas crianças e como considerou a interação das crianças com os materiais e metodologias utilizadas, corroborando com os achados durante as observações.

Pista de carrinhos, a trilha com cano de PVC, rede de vôlei, as casas dos porquinhos com suas portas que abriam e fechavam, o morro e os fantoches da história "Onde a bola foi parar?" (pela possibilidade de movimento), as mangueiras que foram utilizados para fazer as linhas abertas e fechadas (Questionário, 2016).

As interações foram excelentes, mesmo porque as tarefas desenvolvidas trouxeram materiais e estratégias metodológicas que fazem parte do universo e do interesse infantil, como histórias, brincadeiras, jogos ... (Questionário, 2016).

Vale ressaltar que, apesar da qualidade e importância dos materiais, o modo como eles foram utilizados e explorados, por meio das brincadeiras e de outras atividades, foi que propiciou a aproximação das crianças com noções e conceitos matemáticos, expandindo as suas oportunidades de aprendizagem. Desse modo, para ser considerada uma boa tarefa não bastam apenas materiais de qualidade, é preciso atentar para outros aspectos, é preciso que elas sejam autênticas, interessantes, divertidas, variadas e desafiadoras (GUSMÃO, 2014), independentemente do nível educativo ao qual se destina.

No que tange ao aspecto temporal, algumas tarefas tornaram-se longas, diminuindo o interesse e a concentração das crianças, enquanto outras tiveram o tempo adequado, permitindo a participação de todas com interesse e concentração. Para a professora, o tempo longo e a concentração diminuída das crianças foram os pontos negativos que mais lhe chamaram a atenção e também os que geraram mais dificuldade para a gestão das tarefas.

Os aspectos negativos ficaram por conta do tempo de algumas tarefas, principalmente quando uma criança observava a outra realizar a tarefa. Talvez, se o número de crianças envolvido nas tarefas fosse menor, esse problema fosse amenizado (Questionário, 2016).

A maior dificuldade foi em relação ao tempo de concentração das crianças para realização das atividades. Não que as atividades fossem longas demais, mas o grupo era bastante agitado e pouco concentrado. Falo isso comparando com outros grupos da mesma idade que já trabalhei (Questionário, 2016).

Em relação às interações, podemos destacar que, de modo geral, houve um grande envolvimento da professora com as crianças que, de maneira assertiva e afetiva, contribuiu para um bom andamento dos trabalhos. Os processos comunicativos conduzidos por ela, na 
maioria das vezes, promoveram uma exploração mais consistente das noções em contextos diversificados, favorecendo a argumentação e formulação de hipóteses pelas crianças, além de permitir a identificação e resolução de alguns conflitos de significados. Em outros momentos, provocou um conflito de sentido, dificultando o avanço das crianças. Já em relação à interação entre as crianças, podemos destacar o envolvimento e a observação durante as brincadeiras, o que possibilitou aprendizados colaborativos.

Ainda em relação às interações na avaliação da professora,

A interação entre as crianças aconteceu de diversas maneiras, observando e aprendendo com outra que realizava uma tarefa, ouvindo a outra falar, vibrando juntas, brincando juntas (Questionário, 2016).

Quanto à minha interação com o grupo de crianças, acredito ter sido satisfatória. Entretanto, dar conta de contemplar todas as crianças em cada tarefa é mais complicado, pois crianças de 3 anos tem um tempo de concentração pequeno, e o grupo, em que a atividade foi realizada, pela minha experiência, tinha um tempo ainda menor de concentração, mas, na medida do possível, tentamos envolver todas ou o maior número em uma participação ativa, respondendo, opinando... (Questionário, 2016).

A professora destaca, desse modo, a relação direta entre uma boa interação com o componente temporal, quando se trata de tarefas com crianças pequenas, ou seja, a garantia da participação individual de cada criança, respeitando seus limites e individualidade, esbarra no tempo de concentração delas. Assim, entendemos que, mesmo precisando de um tempo maior para dar conta de envolver todas as crianças na tarefa, esta não pode ser demasiado longa, pois provocará a dispersão das crianças, diminuindo o seu engajamento e possíveis oportunidades de aprendizagem.

Com esta análise constatamos que muitos indicadores empíricos previstos no desenho das tarefas foram contemplados durante a sua implementação, alguns de forma integral, outros de forma parcial. Desse modo, consideramos, para esta categoria, que houve, globalmente, uma idoneidade média-alta, tanto na dimensão mediacional quanto na interacional.

\subsection{Avaliação global da idoneidade didática das sequências}

Como destacado anteriormente, a idoneidade didática de um processo de ensino e aprendizagem é avaliada a partir de uma articulação coerente e sistêmica das dimensões epistêmica, cognitiva, interacional, mediacional, afetiva e ecológica. Isso significa dizer que um processo é considerado como idôneo (alta adequação didática) quando há a identificação de graus elevados nas idoneidades parciais. Porém, Font, Planas e Godino (2010) destacam 
que conseguir uma só idoneidade parcial é relativamente fácil, difícil é conseguir a presença equilibrada das seis idoneidades parciais.

Identificamos, na prática, a dificuldade mencionada por esses autores, principalmente quando se trata de um processo de estudo grande, com muitas sequências de tarefas interrelacionadas, pois, apesar de todo processo cuidadoso de buscar contemplar diversos indicadores empíricos durante o desenho das tarefas, na análise das idoneidades parciais, após a implementação, não foi possível constatar um equilíbrio em todas as dimensões, como pode ser visto na Figura 28, que representa a avaliação global da idoneidade didática das sequências.

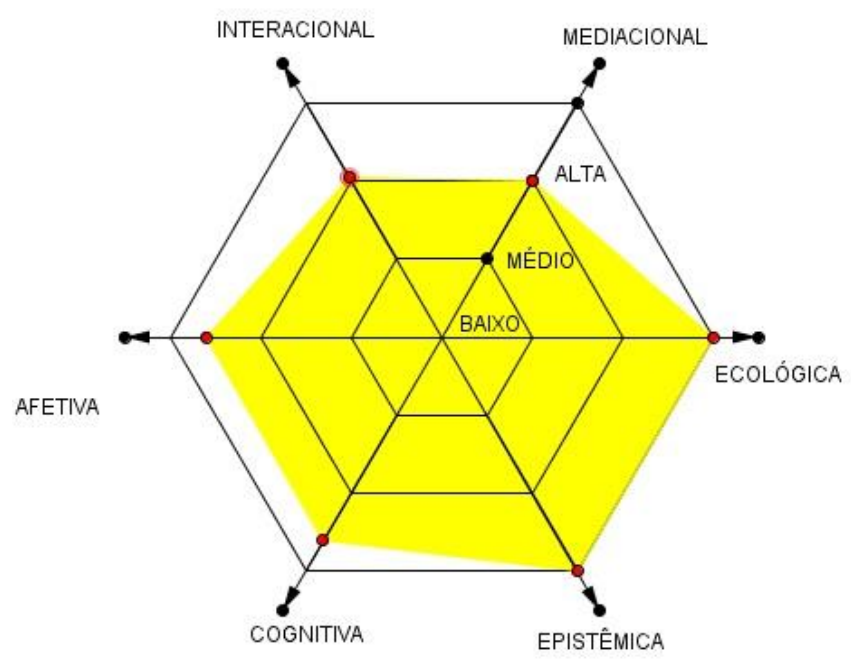

Figura 28 - Mapa da idoneidade didática global das sequências Fonte: Organização nossa, com base em Gondino, Batanero, Font (2008)

Desse modo, podemos inferir que as sequências de tarefas analisadas neste estudo apresentaram idoneidade didática global de média-alta a alta, uma vez que os níveis alcançados nas idoneidades epistêmica e ecológica foram altos, nas idoneidades cognitiva e afetiva moderadamente alto e nas idoneidades mediacional e interacional médio-alto.

\section{Considerações finais}

Com este estudo, pudemos evidenciar que os pontos que potencializaram e os que limitaram as tarefas estiveram associados a diversos aspectos em cada dimensão. As potencialidades puderam ser notadas, de maneira mais elevada, nas idoneidades epistêmica e ecológica, e moderadamente nas idoneidades afetiva, cognitiva, mediacional e interacional. Já os limites apareceram, com um pouco mais de intensidade, nas idoneidades mediacional e interacional e, de forma branda, nas dimensões cognitiva e afetiva. 
Ao considerar que os CID se propõem a fornecer subsídios para a promoção dos ajustes e orientar melhorias dos processos de ensino e aprendizagem (FONT; PLANAS; GODINO, 2010), este estudo serviu, ademais, para extrair conclusões de qual aspecto melhorar, de modo a repensar as tarefas e redesenhá-las, objetivando uma harmonia maior entre as idoneidades e um aumento dos seus níveis.

Nesse sentido, a idoneidade mediacional no componente temporal poderá ser aumentada, se as crianças forem divididas em subgrupos, de modo que todos tenham a oportunidade de participar integralmente das tarefas sem dispersão, caso haja adultos suficientes e espaços disponíveis que permitam a um grupo participar da tarefa, enquanto o outro desenvolve uma atividade diferente, num processo de rodízio, o que contribuiria para uma participação mais engajada, aumentando também a idoneidade afetiva, no componente interesse.

Já a idoneidade interacional, no componente professor/criança, poderá ser aumentada, estimulando as crianças a formularem hipóteses, por meio de diálogo promovidos pelo(a) professor(a). Também poderá ser aumentada a idoneidade interacional, no que diz respeito à relação criança/criança e professor/criança, se o(a) professor(a) aproveitar as hipóteses apresentadas pelas crianças mais expressivas e falantes, direcionando-as para o restante da turma, indagando sobre o que acham, se concordam e o porquê, buscando confrontar e/ou validar as hipóteses, incentivando e valorizando a participação de todos.

\section{Referências}

ALVES-MAZZOTTI, A. J. O método nas Ciências Sociais. In: ALVES-MAZZOTTI, A. J; GEWANDSZNAJDER, F. O método nas ciências naturais e sociais: pesquisa quantitativa e qualitativa. São Paulo: Pioneira, 2000. p. 109-187.

AZEVEDO, P. D.; PASSOS, C. L. B. Professoras da Educação Infantil discutindo a Educação Matemática na infância: o processo de constituição de um grupo. In: CRVALHO, M.; BAIRRAL, M. A. (Org.). Matemática e Educação Infantil: investigações e possibilidades de práticas pedagógicas. Petrópolis: Vozes, 2012. cap. 3.

BRASIL. Ministério da Educação Sec. de Educação Básica. Diretrizes Curriculares Nacionais para a Educação Infantil. Brasília: MEC/SEB, 2010.

CANALS, M. A. Vivir las matemáticas. 3. ed. Barcelona: Octaedro, 2009.

CHAMORRO, M. del C. Didáctica de las Matemáticas na Educacion Infantil. Madrid: Pearson Educación, 2005.

CRECHE UFBA. Projeto Político Pedagógico. Universidade Federal da Bahia, Salvador, 2012. 
De CASTRO, C. La evaluación de métodos para la enseñanza y el aprendizaje de las matemáticas en la Educación Infantil. Revista Iberoamericana de Educação Matemática, n. 11, p. 59-77, 2007.

DUHALDE, M. E.; CUBERES, M. T. G. Encontros iniciais com a Matemática: contribuições à educação infantil. Porto Alegre: Artes Médicas, 1998.

FONT, V.; PLANAS, N.; GODINO, J. D. Modelo para el análisis didáctico en educación matemática. Infancia y Aprendizaje, Madrid, v. 33, n .1, p. 89-105, 2010. Disponível em: http://www.ugr.es/ jgodino/eos/modelo_anadida_25junio09.pdf. Acesso em: 23 de mai. 2015 GODINO, J. et al. Análisis y valoración de la idoneidad didáctica de procesos de estudio de las matemáticas. Paradigma, Maracay, v. XXVII, n. 2, p. 221-252, 2006.

GODINO, J., BATANERO, C., FONT, V. Um enfoque onto-semiótico do conhecimento e a instrução matemática. Acta Scientiae, Canoas, v. 10, n. 2, p. 7-37, jul./dez. 2008.

GODINO, J. D. Indicadores de la idoneidad didáctica de procesos de enseñanza y aprendizaje de las matemáticas. Cuadernos de Investigación y Formación en Educación Matemática, Costa Rica, n. 11, p. 111-132, 2013.

GUSMÃO, T. C. R.S. Desenho de tarefas para o desenvolvimento da cognição e metacognição matemática. In: I Colóquio Internacional Sobre Ensino e Didática das Ciências. Feira de Santana, p.175-180, 2014.

LE BOULCH, J. O desenvolvimento psicomotor - do nascimento até 6 anos. 5. ed. Porto Alegre: Artes Médicas, 1992.

LORENZATO, S. Educação Infantil e Percepção Matemática. Campinas: Autores Associados, 2006.

MEUR, A. de; STAES, L. Psicomotricidade: Educação e Reeducação. Tradução de Ana Maria Izique Galuban e Setsuko Ono. São Paulo: Manole Ltda, 1991.

POCHULU, M. et al. Criterios de diseño de tareas para favorecer el análisis didáctico en la formación de profesores. In: Actas del VII CIBEM, Montevideo, p. 4988-4998, 2013.

SMOLE, K. C. S. A Matemática na Educação Infantil: a Teoria das Inteligências Múltiplas na prática escolar. Porto Alegre: Artmed, 1996.

SMOLE, K. C. S. A Matemática na Educação Infantil. Revista Pátio: Educação Infantil, Porto Alegre, v. 1, n. 38, p. 41-43, jan./mar. 2014.

SMOLE, K. C. S.; DINIZ, M. I. S. V.; CÂNDIDO, P. Figuras e formas. Coleção Matemática de 0 a 6. v. 3, 1. ed. Porto Alegre: Artmed, 2003.

VECINO. F. R. Representación del espacio en el niño. El espacio como modelo de desarrollo de las distintas geometrías. In: CHAMORRO, M. del C. Didáctica de las Matemáticas na Educacion

Infantil. Madrid: Pearson Educación, 2005. p. 255-277.

Submetido em 30 de Junho de 2017. Aprovado em 21 de Novembro de 2017. 